\title{
Mentoring English Senior High School Teachers in EFL Reading Class using collaborative Pamanpintermu at SMAM Bungah Gresik
}

\author{
Author \\ Yudhi Arifani, Harunur Rosyid, Rohmy Husniah \& Paulina \\ Correspondence \\ English Department, Faculty of Teacher Training and Education, \\ Universitas Muhammadiyah Gresik, Indonesia \\ Email: yudhi_arif@umg.ac.id
}

\begin{abstract}
This community engagement is implemented as result of research dissemination on EFL teaching reading. This paper attempts to assist senior high school teachers in implementing the teaching of reading using collaborative Pamanpintermu reading software in EFL classroom. The mentoring program was conducted for six weeks at SMAM Bungah Gresik. Mentoring and Focus Group Discussion (FGD) is employed for the method of the community engagement. The results of Pamanpintermu implementation in the teaching and learning of EFL reading showed positive response from both teachers and students. Through Pamanpintermu, the teachers could monitor students' reading progress and they could more effectively address students' problems in reading class. In the long-term program, it is hoped that Pamanpintermu can be integrated in EFL curriculum at Senior High School in Gresik.
\end{abstract}

Keyword: community engagement, Pamanpintermu, EFL teachers

Received: 30 November 2017. Accepted: 05 January 2018

\section{Introduction}

EFL teachers have essential roles in shaping students' English mastery to develop their critical thinking, independent learning and confidence skills through reading activities. Therefore, teaching reading needs special care and attention from the teachers to shape students' reading habit and to foster critical comprehension as well. Traditionally teaching reading was implemented by asking the students to read the passage one by one in turn and continued with literal comprehension discussion to understand the content of the passage and sometimes the teachers also corrected students' reading errors directly.

Drilling was also done to improve students' reading fluency. Further, students' vocabulary problem was also addressed through translating the difficult words from the teachers or from dictionaries. From those activities it seems that EFL teachers did not understand the objective of teaching reading and students' reading activities do not support their reading habit and their critical reading. Reading is conventionally understood as a receptive skill that does not need to produce any utterance directly. In acquaring the reading skill, students commence with understanding the vocabularies and the knowledge of grammar in their mind. Therefore, most researches on the first language reading have been traditionally concentrated on studying cognitive processes inside the reader's mind (Grabe \& Stoller, 2011; Stevenson, 2010); however, with the development of second language reading research, the focus has currently been expanded to discuss the broader concept of literacy including its variety of aspects of oral, aural, and digital communication (Stevenson, 2010).To address the above issue, the writers attempts to facilitate the use of technology in the teaching reading in order to enhance students' critical reading and reading habit through reading software named as Pamanpintermu.

Pamanpintermu is reading software developed by Arifani and Rosyid (2016) because of two years competitive research grant through awarded by The Ministry of Research and Technology, Directorate of Higher Education (RISTEK DIKTI). It is aimed at assisting the EFL teachers to solve one of the traditional teaching reading issues at school level. The above-mentioned reading software is designed to enhance students' reading critical comprehension, vocabulary, fluency and speed using mobile applications such as cellular phone, 
tablets, and laptop and computer. This reading software has been experimented during one semester at an exemplary senior high school. The result of the experiment revealed that it was able to enhance students' reading performance in terms of reading comprehension, speed, vocabulary, and fluency. From the above phenomena, it is designed to disseminate and mentor EFL teacher to implement Pamanpintermu through collaborative teaching mentoring at senior high school in Bungah Gresik.

In addressing problems or difficulties in reading, the use of suitable computer programs can be the most important aspect. Integrating computer-based reading materials into the EFL learning may have a great potential to enhance reading skills since the design has a cognitive concern which provides access to EFL pedagogy and expertise, innovative tools, and diverse resources culturally and linguistically (Marzban, 2010). Computers can provide powerful scaffolds for children's reading by presenting information flexibly, assessing students' work, and responding to students. It can also present a variety of phonemic awareness practice activities and provide feedback to students and reports to teachers about students' progress (Sherman, Kleiman, Peterson, 2004). In addition, the use of this computer assisted language learning (CALL) programs can help EFL teachers improve learning speed, authenticity, efficiency, and administration. Moreover, CALL also provides individualized instruction which matches with the students' interest, understanding, and pace of learning (Bhatti, 2013).

Pamanpintermu brings communicative CALL because it is corresponded to cognitive theories which recognized that learning was a creative process of discovery, expression, and development. This communicative concern can enhance EFL pupils' English language and curriculum learning by providing and creating opportunities to access information in different and helpful forms, urging learners to refine, develop and store their language output, creating a focus on English and how it is used, increasing opportunities to use first language to support curriculum and English learning, providing opportunities for learners to become autonomous learners and to practice their skills in particular areas of English, increasing motivation to communicate in English, and stimulating working,

thinking, and talking collaboratively (Marzban, 2010).

\section{Purpose of the Dissemination}

The purpose of this dissemination is aimed to mentor EFL teachers at SMA Muhammadiyah Bungah Gresik to enhance their teaching reading using Pamanpintermu.

\section{Method}

The implementation of mentoring EFL teachers in EFL reading class using collaborative Pamanpintermu as part of community engagement at SMAM Bungah Gresik is implemented in partnership between the lecturer from English Department University of Muhammadiyah Gresik and English teachers' association Bungah Subdistrict. The lecturers consisted of two English lecturers specialized in reading skills through six weeks mentoring and focus group discussion. Six senior high school English teachers were involved in this community engagement program. Mentoring activity was conducted by training using Pamanpintermu reading application for the six English teachers using collaborative method. In the training process each detailed component and menu of the reading software was also introduced and shared to all English teachers. After all, six English teachers were able to use the reading software Pamanpintermu automatically and independently the activity then continued by classroom accompaniment during teaching reading class to the students at SMAM Bungah Gresik. Focus group discussion was also conducted to review and to reflect the strength and weaknesses of the program. The detailed implementation is described in table 1 .

Table 1 Implementation of mentoring and FGD community engagement

\begin{tabular}{|c|c|}
\hline Program & Schedule \\
\hline $\begin{array}{l}\text { Socialization and } \\
\text { brainstorming of }\end{array}$ & $\begin{array}{l}\text { Saturday, October 07, } \\
2017\end{array}$ \\
\hline Community Engagement & \\
\hline $\begin{array}{l}\text { Mentoring on the software } \\
\text { usage and modification }\end{array}$ & $\begin{array}{l}\text { Saturday, October 14, } \\
2017\end{array}$ \\
\hline $\begin{array}{l}\text { Training and workshop } \\
\text { how to use all }\end{array}$ & $\begin{array}{l}\text { Saturday, October 21, } \\
2017\end{array}$ \\
\hline $\begin{array}{l}\text { Pamanpintermu Menu } \\
\text { (Practice session 1) }\end{array}$ & \\
\hline $\begin{array}{l}\text { Training and workshop } \\
\text { how to use all }\end{array}$ & $\begin{array}{l}\text { Saturday, October 28, } \\
2017\end{array}$ \\
\hline
\end{tabular}




\begin{tabular}{ll}
\hline \multicolumn{1}{c}{ Program } & \multicolumn{1}{c}{ Schedule } \\
\hline $\begin{array}{l}\text { Pamanpintermu Menu } \\
\text { (Practice session 2) }\end{array}$ & \\
$\begin{array}{l}\text { Accompaniment in } \\
\text { classroom teaching reading } \\
\text { practice using }\end{array}$ & $\begin{array}{l}\text { Saturday, November } \\
04,2017\end{array}$ \\
$\begin{array}{l}\text { Pamanpintermu } \\
\text { (accompaniment 1) }\end{array}$ & \\
$\begin{array}{l}\text { Reflection and Focus } \\
\text { Group Discussion (FD) }\end{array}$ & Saturday, November \\
$\begin{array}{l}\text { Analysis the result of } \\
\text { community engagement } \\
\text { and writing report }\end{array}$ & Saturday, November \\
\end{tabular}

The writers also used interview, observation list and camera recorder to collect the data of the mentoring session and focus group discussion as well as teaching accompaniment in classroom teaching reading using Pamanpintermu. It was then followed by training and workshop on the following week. The workshop consisted of two sections as well. The first workshop session was aimed at practicing

\section{Finding and Discussion}

The first stage was socialization. In this stage, the writers socialize the Pamanpintermu application as part of the research grant awarded by RISTEK DIKTI and recently the agenda was to disseminate the result of research in the form of community service or engagement to disseminate to the six EFL teachers to help them foster their teaching reading objective more effective and more beneficial. All participants welcome the writers' initiation to disseminate the use of Pamanpintermu in teaching reading. A demonstration was also executed to provide comprehensive insight toward the Pamanpintermu reading application. Some teachers deliver question whether the application was modifiable or not so that the material in the reading application could be modified and adjusted to match with the students' reading performance. In addressing this question, the writers' team demonstrate how to modify the reading material starting from the vocabulary menu, reading and reading bar, comprehension questions, reading speed and dictionary text existed in the mobile reading application. Afterward, the team installed the application in the teachers' laptop, tablet and mobile phone. The dissemination program was also communicated and shared as it was written in the table one.
The second stage of the second week of the dissemination, the writers and team conducted two weeks session for mentoring program to understand all functions and menus in the Pamanpintermu reading application. In mentoring session, the team introduce all menus within the reading application. PHP software and its coding were used in the program and explained every part of the system to modify and replace the reading material inside. The most important thing in this mentoring system was to avoid malfunction of the software. It was the essential and important part in mentoring the reading application. In this phase, the teachers were also trained how to create vocabulary survey and reading material match with the students' reading performance level. The result of mentoring session was appreciated by all participants of the six English teachers but again it ran little bit longer as the application was little bit complicated. Consequently, the implementation of mentoring program was implemented for two weeks. The first week was implemented to see and observe teachers' automaticity in operating the use of Pamanpintermu reading application. In addition, the second meeting was used to practice implementing reading application collaboratively in the teaching reading practice within the internal team before they were going to teach reading in the real class situation. Next, in the workshop practice simulation and micro teaching reading practice was conducted for around twice in which all teachers are divided into two groups then they taught within the group using the reading application and within group simulation. First time they seemed that it was little bit challenging to run the application but after they practice twice in the collaborative small group micro-teaching, all the teachers were able to run the application very well and successfully.

Then, the next activity was continued by discussion session and interview. During the discussion session, all teachers were very enthusiastic to attend and join all activities using the reading application. One of the weaknesses for the dissemination was that some of the participants were got difficulty to run the PHP application inside of the reading software. Another weakness was that the modification was only done through computer before the application was distributed into another mobile gadget such as mobile phone and tablets. It happened as mobile gadget did not have PHP 
software as the main bases for running the reading application. Consequently, every teacher who wanted to modify had to do from laptop or computer which had PHP software for modify the content of the application and reading material as well. The mentoring and accompaniment of Pamanpintermu reading was shown in the figure 1 and 2 respectively.

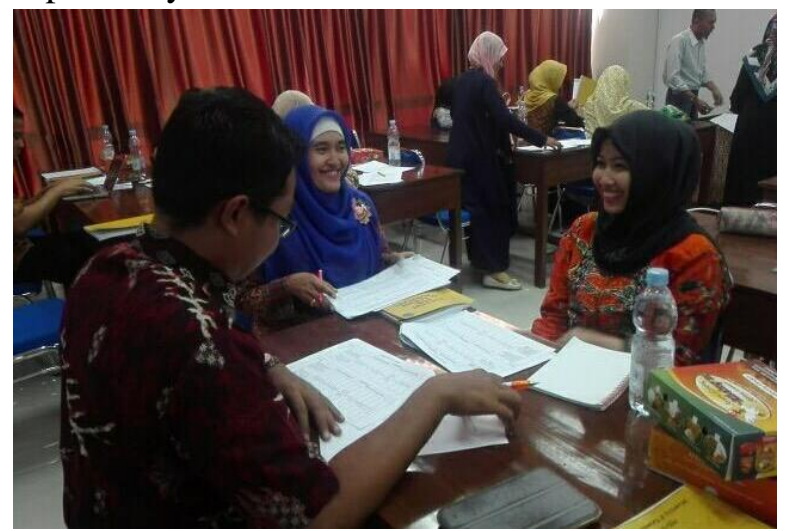

Figure 1. Mentoring and FGD

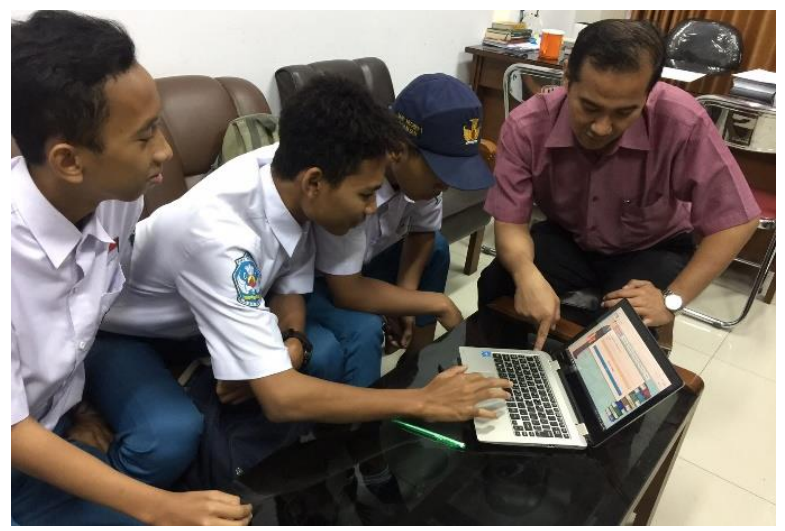

Figure 2. Accompaniment Activity

The following stage was accompaniment in the teaching reading in the real class situation by all EFL teachers. In this case, EFL teachers collaboratively taught in small group consisted of two teachers as facilitator in the teaching of reading in the real classroom situation. Meanwhile other teachers became an observer to observe all classroom teaching reading activities. In this occasion, the writer and team did not monitor at glance on the classroom implementation as they had already been equipped with mentoring, workshop and discussion to implement the reading application but on the following session the writer and team as well as with all teachers guide them to reflect their implementation result in a focus group discussion prepared before.
One of advantages of using collaborative teaching was they can provide better reflection and teaching improvement as all of them were observe the classroom teaching and learning. After class they could share with their colleagues to improve their classroom teaching. Weaknesses on the teaching implementation especially how students learned reading through the application was the main concern on observation and reflection stages. They were not allowed to comment and judge on the teachers' ways of teaching as it would cause uneasiness toward all teachers. So, the focus of observation and reflection was to improve students' learning reading activity.

Result of interview with all English teachers in the focus group discussion revealed that it was challenging and new experience for the as they usually taught reading flew from their personal experience. They never read an article or journal on the objective and goals of teaching reading so that teaching reading is not optimal yet. So, it was difficult to measure their reading development and weaknesses. Through reading application Pamanpintermu, the teachers could facilitate individual reading, monitor students' reading development, assess reading performance more accurately and treat students' error more appropriately based on their reading performance problems.

\section{Conclusion}

The implementation of mentoring and focus group discussion implemented to EFL teachers using collaborative Pamanpintermu mobile reading application is able to facilitate EFL teachers using mobile application to foster students' reading comprehension. It is also easier to monitor and assess individual student's reading progress and development. Implementation of teaching reading collaboratively is considered as one of effective ways to reflect teachers' teaching ability in the classroom. Reading as a technology has always produced different degrees of success but with more technology the differences have probably become greater (Cobb, T., 2015).

Mentoring and FGD is also a good media to discuss their reading problem and as a media to solve or address the teaching problem. Consequently, to be professional English teachers 
could be facilitated through collaborative teaching with other EFL teachers.

\section{Reference}

Arifani, Y., \& Rosyid, H. (2016). Integrating reading and technology: the development of Pamanpintermu. English Language Teaching, $9(11)$, 13-28. http://dx.doi.org/10.5539/eltv9n11p13

Arifani, Y. (2016). The Implementation of Team Based Discovery Learning to Improve Students' Ability in Writing Research Proposal. English Language Teaching, 9(2), 111-119. http://dx.doi.org/10.5539/ies.v9n2p111

Bhatti, T. M. (2013). Teaching Reading through Computer-Assited Language learning. TESL-EJ, 17(2).

Cobb, T. (2015). Technology for Teaching Reading. TESOL Encyclopedia of English Language Teaching. New York, Wiley-Blackwell.

Grabe, W., \& Stoller, F. L. (2011). Teaching and researching reading. Essex: Pearson Education Limited.

Marzban, A. (2010). Improvement of Reading Comprehension through Computer-Assisted Language Learning in Iranian Intermediate EFL Students. Procedia Computer Science 3 (2011) $3-10$.

Sherman, D., Kleiman, G., \& Peterson, K. (2004). Technology and Teaching Children to Read. Education Development Center, Inc.

Stevenson, M. (2010). Researching reading. In B. Paltridge \& A. Phakiti (Eds.), Continuum companion to research methods in applied linguistics (pp. 174-190). London: Continuum International Publishing Group. 